\title{
Correlation between electroretinogram findings and molecular analysis in the Duchenne muscular dystrophy phenotype
}

\author{
Inge De Becker, D Christine Riddell, Joseph M Dooley, François Tremblay
}

\begin{abstract}
Fifteen consecutive patients with the Duchenne muscular dystrophy (DMD) phenotype were studied. Each patient was asked to undergo an ophthalmic examination, an electroretinogram (ERG), and to donate a blood sample for molecular diagnosis. All 15 patients had a normal ophthalmic examination. Electroretinography was successful in 14/15 patients. The ERG tracings were normal in seven patients, abnormal in seven, and unreliable in one. Blood for molecular analysis was obtained in $12 / 15$ patients. In the seven patients with a normal ERG, five underwent molecular analysis, and in these five no deletion was detected in the dystrophin gene. In the seven patients with an abnormal ERG, six had molecular analysis available, and all six were found to have a deletion. These results suggest that patients with a classic DMD phenotype are genetically heterogeneous, and that this heterogeneity is reflected in the ERG. (BrF Ophthalmol 1994; 78: 719-722)
\end{abstract}

Duchenne muscular dystrophy (DMD) is one of the most common and severe neuromuscular disorders, with an incidence of one in 3500 newborn males, ${ }^{1}$ and a prevalence of $2 \cdot 48 /$ 100000 in the general population. ${ }^{2}$ The muscle atrophy progresses rapidly: patients are classically wheelchair bound by the age of 12 and die of respiratory insufficiency or cardiac failure in their early twenties. ${ }^{3}$

In $\mathrm{DMD}$, the large causative gene located at Xp21 may undergo deletions, duplications, or point mutations. The defective protein product, dystrophin, is produced inadequately to maintain its normal functions..$^{3-5}$ Dystrophin is a very high molecular weight protein essential to the cytoskeleton of striate muscle. ${ }^{67}$ Dystrophin deficient fibres have a mechanically weakened plasma membrane ${ }^{8}$ and may have abnormal calcium channels. ${ }^{9}$ Several isoforms of dystrophin exist. ' Some are found in neurons and glial cells of the central nervous system, ${ }^{1011}$ where they seem to localise more specifically to dendrites and synaptic regions, thus suggesting a role in neurotransmission. ${ }^{12}$ Other dystrophin isoforms are present in normal human retina at the level of the outer plexiform layer and it has been reported that patients with DMD have an electronegative scotopic ERG. ${ }^{1{ }^{14}}$ It has been suggested that the ERG could become a noninvasive probe to measure the DMD gene function, or a diagnostic or prognostic tool for DMD. ${ }^{1314}$

Because approximately $35 \%$ of patients with
DMD have no identifiable deletion in the dystrophin gene, ${ }^{3}$ we chose to study 15 consecutive patients with DMD phenotype, rather than only those with a proved deletion. We report on the ophthalmic findings, the ERG, and the molecular analysis in these subjects.

\section{Materials and methods}

\section{PATIENTS}

Fifteen consecutive patients with a DMD phenotype were identified from the neuromuscular clinic. The diagnostic criteria are described in Table 1. Molecular diagnosis was not part of the diagnostic criteria. All 15 patients were asked to undergo an ocular examination and electroretinography, as well as to donate a blood sample for molecular analysis. One DMD patient followed at our institution has complex glycerol kinase deficiency (CGKD), a contiguous gene syndrome of the $\mathrm{Xp} 21$ region. This patient was included in a previous report, ${ }^{15} 16$ and he did not participate in the present study.

\section{MOLECULAR ANALYSIS}

Blood was collected in EDTA vacutainer tubes and the DNA extracted by standard procedures. ${ }^{17}$ The samples were examined for commonly deleted regions of the DMD gene by PCR amplification using the multiplex conditions of Chamberlain et al ${ }^{18}$ and Beggs et al. ${ }^{19}$ These reactions will detect $98 \%$ of DMD deletions. In those patients in which deletions were not detected by multiplex PCR, Southern blots were performed using the probes cDMD 4-5a (ATCC), cDMD 5b-7 (ATCC), and J66 (van Ommen, Leiden) to examine regions of the DMD gene less commonly involved in deletions.

\section{OPHTHALMIC EXAMINATION}

Each patient was asked with insistence about the presence of nyctalopia or any other ocular complaint. Visual acuity was measured with a portable illuminated HOTV chart calibrated for use at 3 metres. Pupils were examined for afferent defect or paradoxical reaction. Nystagmus was looked for clinically. Dilated fundus examination was done with direct and indirect ophthalmoscopy, and attention was paid particularly to the aspect and coloration of the optic nerves, the retinal blood vessels, the maculae, the quality of the foveal reflex, and the overall chorioretinal background. A cycloplegic refraction was done if uncorrected visual acuity was less than $1 \cdot 0(6 / 6)$ in either eye. 
Table 1 Diagnostic criteria for DMD phenotype, molecular analysis, and ERG findings

\begin{tabular}{|c|c|c|c|c|c|c|c|c|c|}
\hline \multirow[b]{2}{*}{ Case } & \multirow[b]{2}{*}{ Age } & \multicolumn{6}{|c|}{ Diagnostic criteria } & \multirow{2}{*}{$\begin{array}{l}\text { DNA } \\
\text { deletion } \\
\text { (exons) }\end{array}$} & \multirow[b]{2}{*}{$E R G$} \\
\hline & & $\begin{array}{l}\text { Muscle } \\
\text { weakness }\end{array}$ & $\begin{array}{l}\text { Muscle } \\
\text { biopsy }\end{array}$ & $\begin{array}{l}\text { Elevated } \\
\text { CPK }\end{array}$ & $E M G$ & $F H$ & $W C B$ & & \\
\hline $\begin{array}{r}3 \\
4 \\
5 \\
9 \\
1 \\
8 \\
15\end{array}$ & $\begin{array}{r}20 \\
24 \\
15 \\
16 \\
22 \\
5 \\
4\end{array}$ & $\begin{array}{l}+ \\
+ \\
+ \\
+ \\
+ \\
+ \\
+\end{array}$ & $\begin{array}{l}+ \\
+ \\
+ \\
+ \\
+ \\
+ \\
+\end{array}$ & $\begin{array}{l}+ \\
+ \\
+ \\
+ \\
+ \\
+ \\
+\end{array}$ & $\begin{array}{l}+ \\
\text { ND } \\
\text { ND } \\
\text { ND } \\
\stackrel{+}{N D} \\
\text { ND }\end{array}$ & $\begin{array}{l}- \\
- \\
- \\
- \\
- \\
- \\
-\end{array}$ & $\begin{array}{c}9 \\
10 \\
10 \\
8 \\
10 \\
\text { NY } \\
\text { NY }\end{array}$ & $\begin{array}{l}47 \\
45 \\
49-52 \\
45-48 \\
\text { ND } \\
3 \\
48-51\end{array}$ & $\begin{array}{l}\text { Electronegative } \\
\text { Electronegative } \\
\text { Electronegative } \\
\text { Electronegative } \\
\text { Electronegative } \\
\text { Electronegative } \\
\text { Electronegative }\end{array}$ \\
\hline $\begin{array}{r}2 \\
10 \\
6 \\
13 \\
7 \\
12 \\
14\end{array}$ & $\begin{array}{l}15 \\
24 \\
11 \\
22 \\
17 \\
10 \\
19\end{array}$ & $\begin{array}{l}+ \\
+ \\
+ \\
+ \\
+ \\
+ \\
+\end{array}$ & $\begin{array}{l}+ \\
+ \\
+ \\
+ \\
+ \\
+\end{array}$ & $\begin{array}{l}+ \\
+ \\
+ \\
+ \\
+ \\
+ \\
+\end{array}$ & $\begin{array}{l}\text { ND } \\
+ \\
\text { ND } \\
+ \\
+ \\
+ \\
+\end{array}$ & $\begin{array}{l}+ \\
- \\
- \\
- \\
- \\
- \\
+\end{array}$ & $\begin{array}{l}9 \\
12 \\
\mathrm{NY} \\
13 \\
12 \\
\mathrm{NY} \\
12\end{array}$ & $\begin{array}{l}\text { ND } \\
\text { No deletion } \\
\text { ND } \\
\text { No deletion } \\
\text { No deletion } \\
\text { No deletion } \\
\text { No deletion }\end{array}$ & $\begin{array}{l}\text { Normal } \\
\text { Normal } \\
\text { Normal } \\
\text { Normal } \\
\text { Normal } \\
\text { Normal } \\
\text { Normal }\end{array}$ \\
\hline 11 & 7 & + & + & + & ND & - & NY & No deletion & Unreliable \\
\hline
\end{tabular}

Elevated $\mathrm{CPK}=$ creatine phosphokinase $>140 \mu \mathrm{m} / \mathrm{ml}$; muscle biopsy =dystrophy changes observed; $\mathrm{EMG}=$ electromyography; $\mathrm{FH}=$ family history; $\mathrm{WCB}=$ age at which the patient is wheelchair bound; $\mathrm{ERG}=$ electroretinogram in response to bright flash stimulation; $\mathrm{ND}=$ not done; $\mathrm{NY}=$ not yet wheelchair bound

\section{ELECTRORETINOGRAPHY}

All ERGs were done without sedation. The electroretinographic procedure used in this study has been described in full detail elsewhere. ${ }^{20}$ Briefly, this included an initial period of 30 minutes of dark adaptation under controlled dim red illumination during which the procedures were explained to the patient. Cutaneous gold electrodes were fixed to the forehead (reference) and right earlobe (ground) after skin preparation. After pupil dilatation and topical corneal anaesthesia, a contact lens (Lovac type, Medical Workshop, the Netherlands) was set on the cornea. In one young uncooperative patient, a carbon fibre electrode (Instruments for Medicine, Salt Lake City, USA) was placed in the inferior conjunctival fornix. A Ganzfeld stimulator (Nicolet GS2000, Madison, USA) produced a series of short (Kodak Wratten No 47, a, b, Rochester, USA) and long (Kodak Wratten No 26) wavelength stimulation in scotopic conditions, in order to characterise the dark adapted rod and cone components. Bright white flash stimulations $\left(0.8 \mathrm{~cd} \cdot \mathrm{m}^{2} \cdot \mathrm{s}\right)$ were also used to estimate the total retinal output. Single white flash stimulation $\left(10 \cdot 1 \mathrm{~cd} \cdot \mathrm{m}^{2} \cdot \mathrm{s}\right)$ under photopic conditions $\left(34 \mathrm{~cd} \cdot \mathrm{m}^{2}\right)$ and $33.3 \mathrm{~Hz}$ flicker stimulation were delivered after a minimum of 3 minutes of light adaptation to provide an estimate of the cone activity. The amplifier's bandpass was set at $1 \mathrm{~Hz}$ to $1 \mathrm{kHz}$ in a first channel to record the standard ERG and in a second channel to $100 \mathrm{~Hz}$ to $1 \mathrm{kHz}$ to record the oscillatory potentials (OPs). An artefact rejection device eliminated data contamination from eye movements and an averager (Nicolet PathFinder II) cumulated and stored the raw data. This procedure fulfils the minimum requirements as stated by the International Society for Clinical Electrophysiology of Vision's Standardisation Committee. $^{21}$

\section{STATISTICAL ANALYSIS}

For the ERG results, a $t$ test (two tails, 0.05 level) was used to compare the group average of each of the parameters measured to a normative group, which contained 24 normal patients age-matched with the DMD group (aged 5-24 years; mean 16 years).

\section{Results}

Fifteen consecutive males with a DMD phenotype, age 5 to 24 years, were examined. The 10 oldest patients were wheelchair bound. Visual acuity was $1.0(6 / 6)$ or better in all eyes examined, except for one, that had suffered a
Figure 1 Representative electroretinograms in DMD patients with (recordings 1-3) and without (recordings 4-6) electronegative ERG to scotopic bright flash stimulation. The top line illustrates the cone related responses after adaptation to a photopic background. The second line shows recordings of the rod related component, after 30 minutes of dark adaptation. The

characteristic response to a bright flash is in the bottom line. Examples of normal recordings are provided in the right hand column.

Arrowhead = stimulus onset. Horizontal calibration mark $=20$ ms (traces $1,4,7$ ), 40 ms (traces 2, 3, 5, 6, 8, and 9). Vertical calibration mark $=100 \mu \mathrm{V}$.

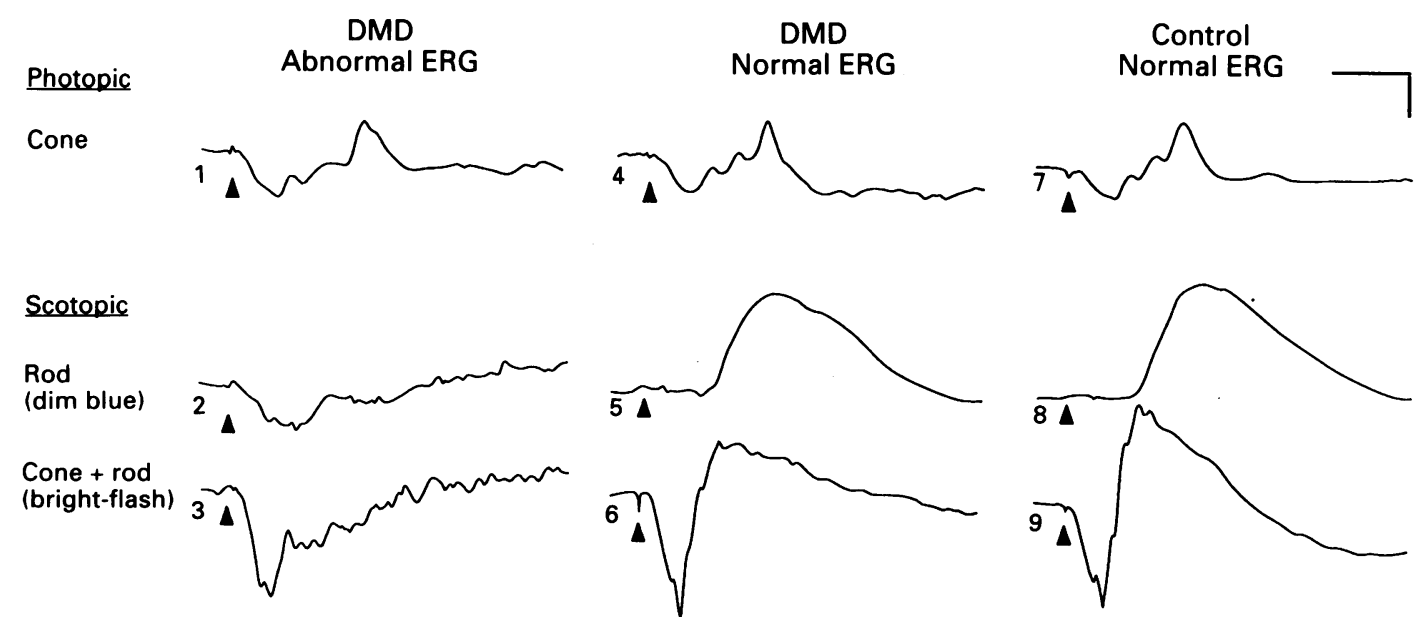


Table 2 Quantitative data and statistical analysis of electroretinographic findings in patients with Duchenne muscular dystrophy

\begin{tabular}{|c|c|c|c|c|c|}
\hline$E R G$ measurements & $\begin{array}{l}\text { Duchenne } \\
\text { abnormal }\end{array}$ & $p$ & $\begin{array}{l}\text { Duchenne } \\
\text { normal }\end{array}$ & $p$ & $\begin{array}{l}\text { Normal age } \\
\text { matched }\end{array}$ \\
\hline \multicolumn{6}{|l|}{ Amplitude $(\mu \mathrm{V})(\mathrm{SD})$} \\
\hline \multicolumn{6}{|l|}{ Photopic: } \\
\hline $\begin{array}{l}\text { a-Wave } \\
\text { b-Wave }\end{array}$ & $\begin{array}{r}82(20) \\
159(36)\end{array}$ & $\begin{array}{l}0 \cdot 68 \\
0 \cdot 19\end{array}$ & $\begin{array}{r}88(15) \\
178(20)\end{array}$ & $\begin{array}{l}0.18 \\
0.96\end{array}$ & $\begin{array}{r}79(17) \\
178(45)\end{array}$ \\
\hline \multicolumn{6}{|l|}{ Scotopic: } \\
\hline Rod b-wave & $140(37)$ & $<0.001$ & $418(60)$ & 0.37 & $413(81)$ \\
\hline Bright-flash, a-wave & $229(43)$ & 0.09 & $256(120)$ & $0 \cdot 29$ & $262(47)$ \\
\hline Bright-flash, b-wave & $128(55)$ & $<0.001$ & $469(85)$ & 0.92 & $516(100)$ \\
\hline b/a Ratio & $0 \cdot 58(0 \cdot 23)$ & $<0.001$ & $2 \cdot 07(0 \cdot 23)$ & & $2.00(0.33)$ \\
\hline \multicolumn{6}{|l|}{ Implicit time (ms) (SD) } \\
\hline \multicolumn{6}{|l|}{ Photopic: } \\
\hline a-Wave & $14 \cdot 3(1 \cdot 5)$ & 0.006 & $13 \cdot 5(0 \cdot 8)$ & $0 \cdot 13$ & $13 \cdot 2(0 \cdot 4)$ \\
\hline b-Wave & $36 \cdot 4(2 \cdot 3)$ & 0.02 & $33 \cdot 9(1 \cdot 0)$ & $0 \cdot 39$ & $34 \cdot 6(1 \cdot 7)$ \\
\hline \multicolumn{6}{|l|}{ Scotopic: } \\
\hline Rod b-wave & $53 \cdot 3(3 \cdot 4)$ & $0 \cdot 15$ & $57 \cdot 8(2 \cdot 7)$ & 0.06 & $55 \cdot 5(29)$ \\
\hline Bright-flash, a-wave & $22 \cdot 7(0 \cdot 9)$ & 0.68 & $23.8(1.9)$ & 0.03 & $22 \cdot 8(0 \cdot 6)$ \\
\hline Bright-flash, b-wave & $37 \cdot 1(4 \cdot 1)$ & $<0.001$ & $45 \cdot 3(2 \cdot 7)$ & 0.56 & $45 \cdot 1(1 \cdot 8)$ \\
\hline
\end{tabular}

$\mathrm{p}=\mathrm{p}$ Value, $t$ test, two tailed.
In the present study only $50 \%$ of the patients with DMD have an electronegative ERG, while the other $50 \%$ have a normal ERG. This is possibly because we studied 15 consecutive patients with a classic DMD phenotype, rather than patients with a proved DMD genotype. It could also be that our DMD population differs from that studied in other geographical areas. In our series, patients with no detectable deletion in the dystrophin gene also had a normal ERG. It is possible that these patients have a smaller undetected mutation in the dystrophin gene or a duplication, not affecting normal transcription of the retinal isoforms. They may also have a mutation involving the promoter region for the striate muscle isoforms and not the brain and/or retinal isoforms. It is known that brain dystrophin and striate muscle dystrophin use different promoters. ${ }^{71}$ It is possible, but less likely, that a protein other than dystrophin is involved, such as a 'dystrophin associated protein' (DAP), ${ }^{23}$ and 'dystrophin related protein', which maps to chromosome 6 , is an autosomal homologue of dystrophin, ${ }^{24} 25$ causing a classic DMD phenotype, but no ERG abnormalities.

In conclusion, these results indicate there is genotypic and ERG heterogeneity within our group of patients with a classic DMD phenotype. There seems to be a correlation between the genotype and the ERG findings: our patients with a deletion have perturbed ERG while those with no detectable deletion have a normal ERG. This suggests that patients with DMD phenotype and a normal ERG may have an as yet undetected mutation in the dystrophin gene that does not affect the retinal isoforms. They could also have an intact dystrophin gene but an altered promotor. Lastly, it is possible that both the dystrophin gene and the promotor are intact and that the anomaly lies in a dystrophin related protein.

We wish to thank all the families who kindly gave their time to participate in this study. Many thanks also to Kevin Gordon, MD, for referring some patients, and to Judy MacSween, Brenda Walmsley, and Claudia MacPhee for the difficult task of coordinating the patients' appointments.

Presented in part at the Association for Research in Vision and Ophthalmology, Sarasota, 4 May 1993.

1 Worton RG. Duchenne muscular dystrophy: gene and gene product; mechanism of mutation in the gene. $\mathcal{F}$ Inherit Metab Dis 1992; 15: 539-50.

2 Gardner-Medwin D, Sharples P. Some studies of the Duchenne and autosomal recessive types of muscular dystrophy. Brain Develop 1989; 2:91-7.

3 Bushby KMD. Genetic and clinical correlations of Xp21 muscular dystrophy. $\mathcal{F}$ Inherit Metab Dis 1992; 15: 551-64. muscular dystrophy. F Inhert Metab Dis 1992; 15: $551-64$.
Koening M, Beggs AH, Mayer M. The molecular basis for Duchenne versus Becker dystrophy: correlation of severity with type of deletion. Am F Hum Genetics 1989; 45: 498-506.

5 Worton RG, Thompson MW. Genetics of Duchenne muscular dystrophy. Ann Rev Genet 1988; 22: 601-29.

6 Zubrzycka-Gaarn EE, Bulman DE, Karpati G, Burghes AHM, Belfall B, Klamut HJ, et al. The Duchenne muscular dystrophy gene product is localized in the sarcolemma of human skeletal muscle. Nature 1988; 333: 466-9.

7 Ahn AH, Kunkel LM. The structural and functional diversity of dystrophin. Nature Genetics 1993; 3: 283-91.

8 Menke A, Jockuses $\mathrm{H}$. Decreased osmotic stability of dystrophinless muscle from dmx mouse. Nature 1991; 335: 334-6. phinless muscle from dmx mouse. Nature 1991; 335: 334-6.
Franco A, Lansman JB. Calcium entry through stretchinactivated ion channels in dmx myotubes. Nature 1990; inactivated

10 Boyce FM, Beggs AH, Feener C, Kunkel LM. Dystrophin is transcribed in brain from a distant upstream promoter. Proc Nat Acad Sci USA 1991; 88: 1276-80.

11 Chelly J, Hamard G, Koulakoff A, Kaplan J-C, Kahn A, Berwald-Netter $Y$. Dystrophin gene transcribed from different promoters in neuronal and glial cells. Nature 1990; 344: 64-5.

12 Lidov HGW, Byers TJ, Bobrow M, Bently DR. Localization of dystrophyn to post-synaptic regions of central nervous system cortical neurons. Nature 1990; 348: 725-8. of which 31 had an abnormal ERG. ${ }^{22}$ Cibis et al ${ }^{14}$ report five DMD patients with an abnormal ERG. 
13 Pillers D-AM, Bulman DE, Weleber RG, Sigesmund DA, Musarella MA, Powell BR, et al. Dystrophin expression in the human retina is required for normal function as defined by electroretinography. Nature Genetics 1993; 4: 82-6.

14 Cibis GW, Fitzgerald KM, Harris DJ, Rothberg PG, Rupan $M$. The effect of dystrophin gene mutation on the ERG in mice and humans. Invest Ophthalmol Vis Sci 1993; 34: 3646-52.

15 Weleber RG, Pillers DM, Powell BR, Hanna CE, Magenis E, Buist NRM. Aland island eye disease (Forsius-Eriksson syndrome) associated with contiguous deletion syndrome at Xp21. Similarity to incomplete congenital stationary night Xp21. Similarity to incomplete congenital station
blindness. Arch Ophthalmol 1989; 107: 1170 9 .

16 Pillers D-AM, Seltzer WK, Powell BR, Ray PN, Tremblay F LaRoche GR, et al. Negative-configuration electroretinogram in Oregon eye disease: consistent phenotype in $\mathrm{Xp2}$ deletion syndrome. Arch Ophthalmol 1993; 111: 1558-63.

17 Miller SA, Dykes DD, Polesky HF. A simple salting ou procedure for extracting DNA from human nucleated cells. Nucleic Acids Res 1988; 16: 1215 .

18 Chamberlain JS, Gibbs RA, Ranier JE. Multiplex PCR for the diagnosis of Duchenne muscular dystrophy. In: Innis MA, Gelfand DH, Sninsky JJ, White TJ, eds. PCR Protocols. A guide to methods and applications. London: Academic Press, guide to methods
1990: 272-81.
19 Beggs AH, Koenig M, Boyce FM, Kunkel LM. Detection of $98 \%$ of DMD/BMD gene deletions by polymerase chain reaction. Hum Genet 1990; 86: 45-8.

20 Tremblay F, LaRoche GR, Shea SE, Ludman MD Longitudinal studies of the early electroretinographic changes in Alström syndrome. Am $\mathcal{F}$ Ophthalmol 1993; 115: $657-65$

21 Marmor MF, Arden GB, Nilsson SEG, Zrenner E. Standard for clinical electroretinography. Arch Ophthalmol 1989; 107: 816-9.

22 Pillers DM, Sigesmund DA, Ray PN, Musarelle MA, Tremblay F, Seltzer WK, et al. Genotype-phenotype correlations identified by electrophysiology of the retina in Duchenne and Becker muscular dystrophy patients. $A m \mathcal{F}$ Hum Genet 1993; 53 (suppl): 3, Presentation 146.

23 Matumura K, Tomé FMS, Collin H, Azibi K, Chaouch M, Kaplan J-C, et al. Deficiency of the $50 \mathrm{~K}$ dystrophinassociated glycoprotein in severe childhood autosomal recessive muscular dystrophy. Nature 1990; 359: 320-2

24 Love DR, Hill DF, Dickson G, Spurr NK, Byth BC, Marsden $\mathrm{RF}$, et al. An autosomal transcript in skeletal muscle with homology to dystrophin. Nature 1989; 339: 55-8.

25 Tinsley JM, Blake DJ, Roche A, Fairbrother U, Riss J, Byth $\mathrm{BC}$, et al. Primary structure of dystrophin-related protein. Nature 1992; 360: 591-3. 